\title{
COMPARATIVE STUDY OF THE PROXIMATE COMPOSITION OF SOME WILD TILAPIINE FISHES IN EPE LAGOON, LAGOS, NIGERIA
}

\author{
BOMBATA-FASHINA ${ }^{1}$, H.A; MEGBOWON I. ${ }^{2}$, OKUNADE OLUMIDE ${ }^{2}$, OZOR P.A ${ }^{2}$, IBRAHIM, A.O ${ }^{2}$, \\ ADEJONWO O.A ${ }^{2}$ AND KOLADE O.Y. ${ }^{2}$ \\ ${ }^{1}$ Faculty of Science, Lagos State University, Ojo, Lagos \\ ${ }^{2}$ Nigerian Institutes for Oceanography and Marine Research, Victoria Island, Lagos.
}

Copyright 2010, Fisheries Society of Nigeria.

This paper was prepared for presentation at the $25^{\text {th }}$ Annual International Conference and Exhibition in Administrative Staff College of Nigeria (ASCON), Topo-Badagry, Lagos, Nigeria, $25^{\text {th }}-29^{\text {th }}$ October, 2010.

This paper was selected for presentation by an FISON Program Committee following review of information contained in an abstract submitted by the author(s). Contents of the paper, as presented, have not been reviewed by the Fisheries Society of Nigeria and are subject to correction by the author(s). The material, as presented, does not necessarily reflect any position of the Fisheries Society of Nigeria, its officers, or members. Papers presented at FISON meetings are subject to publication review by Editorial Committees of the Fisheries Society of Nigeria. Electronic reproduction, distribution, or storage of any part of this paper for commercial purposes without the written consent of the any part of this paper for comment Fisheries Society of Nigera is prohibited. Permission to reproduce in print is restricted to an abstract of not more than 300 words; illustrations may not be copied. The abstract must contain conspicuous acknowledgement of where and by whom the paper was presented. Write Librarian, Fisheries Society of Nigeria (FISON), P. O. Box 2607 Apapa, Lagos.

\section{ABSTRACT}

The proximate composition of some wild tilapiine fishes in Epe lagoon, Lagos, Nigeria was analyzed. The species were Sarotherodon melanotheron, Tilapia guineensis, Tilapia mariaei, Sarotherodon galileaus and an ecotype cichlid popularly called 'wesafu'. Major nutrient compositions of raw muscles like protein, fat, moisture and ash were determined. Proximate compositions were found to be varied among the species. Protein was determined in Sarotherodon melanotheron (19.13\%), T. guineensis (18.71\%), T. mariae (18.08\%), $S$. galileaus (18.34\%) and 'wesafu' (21.80\%) respectively. Lipid content was recorded as $0.82 \%, 0.40 \%, 0.60 \%, 0.65 \%$, and $0.90 \%$ for the tilapia species. The highest level of moisture content was found in $T$. guineensis $(81.70 \%)$ and the lowest was in 'wesafu' $(78.50 \%)$. The percentage of ash content was highest in $S$. galileaus and S.melanotheron $(1.75 \%)$ and lowest in $T$. guineensis (1.00\%). The present study revealed highest protein content in the ecotype cichlid, wesafu (19.22\%) and lowest value in T.mariae $(18.08 \%)$ while fat was highest in 'wesafu' $(0.90 \%)$. The results of this study reveal the nutritional significance of the ecotype cichlid, 'wesafu' above other cichlids of the lagoon.

Key words: Proximate composition, Tilapiine fishes, Epe Lagoon,

\section{INTRODUCTION}

On a global basis, tilapia has become the second most commonly consumed farmed fish after carps (Fitzisimmons, 2008). The relative environmental friendliness of tilapia production, along with diversified production strategies and strong domestic market in producing countries as well as growing International trade will drive tilapia production and demand globally. Tilapias are omnivorous fish which naturally feed on plankton, diatoms, small crustaceans, higher plants and decomposing vegetative matters. Historically they have been utilized to recycle wastes into high quality flesh (Alkobaby et al, 2008). They are capable of digesting high level of carbohydrate in their diet. The diet of fish has a great influence on their general chemical composition, and particularly on their fatty acid composition (Henderson and Tocher, 2007). The chemical composition of fish muscle varies from one species to another and individuals within the same species (Alkobaby et al, 2008). Such variation depends on the age, size, sex, environment and season. In fact the variation in the chemical composition of fish is closely related to the feed intake, migratory pattern, swimming and sexual changes in connection with spawning (Sallam et al., 2007). 
The study was conducted to assess the proximate composition of the tilapiine fishes of Epe lagoon; namely Sarotherodon melanotheron, Tilapia guineensis, Tilapia mariae, Sarotherodon galileaus and an ecotype cichlid, 'wesafu', endemic to Epe lagoon.

\section{MATERIALS AND METHODS}

Sampling: Fresh specimens of Tilapiine fishes were purchased from fishermen at Epe lagoon landing site in Lagos state. The samples were collected aseptically and transported in an insulated container under chilled condition to the Fish Technology laboratory, Nigerian Institute for Oceanography and Marine Research Victoria Island, for analysis.

\section{Proximate Composition Analysis:}

Proximate analyses were carried out in triplicate determination on the samples after dressing. These analyses include moisture content, total lipid, crude protein and ash. The moisture content was determined by drying samples to constant weight at $105 \pm 2^{0} \mathrm{C}$ using the oven dry method (AOAC, 1994). Lipid determination was carried out using the modified Bligh and Dyer procedure (AOAC, 1994). The ash content of the fish samples were determined by igniting the samples at $550^{\circ} \mathrm{C}$ for 5 6hours until the samples were completely free of carbon particles in a carbotite Sheffield LMF3 muffle furnace while the total nitrogen was determined by the Kjedahl method as described by Vlieg, 1984 and a factor of 6.25 was used for converting the total nitrogen to crude protein content of the fish samples.

\section{RESULTS}

Table 1 below showed the results of the proximate composition of wild samples of the cichlid fishes. The moisture content was in the range of (78.50-81.70\%), lipid (0.40-
$0.9 \%)$, and ash (1.00-1.75\%) while protein was in the range of (18.08-21.80\%)

\section{DISCUSSION}

The protein content, 18.34\%, $19.13 \%$, $18.71 \%, 18.08 \%$ and $21.80 \%$ for T. galileus, $S$. melanotheron, $T$. guineensis, $T$. mariae and Wesafu respectively vary considerably from species to species. This is in agreement with Alkobaby et al.(2008) who reported that the chemical composition of fish muscle varies greatly from species to species and even among the individuals within the same species. According to the author, such variation depends on age, size, sex, environment and season. Sallam et al., (2007) further stressed that the variation is closely related to feed intake, migratory, swimming and sexual changes in connection with spawning. The highest percentage of protein for 'wesafu' in this study is probably due to presence of certain amino acids in 'wesafu' which may be absent in other cichlids studied. Hammed et al, (In-press) reported that 'wesafu' has the highest value of Phenylalanine, Isoleucine, Leucine and Valine than other cichlids studied. The results of the lipid content revealed that the ecotype cichlid, 'Wesafu' has the highest lipid content $(0.9 \%)$ while $T$. guineesis has the least $(0.4 \%)$. The results obtained showed that the fish species studied belong to the low-oil category and therefore can be classified as lean fish. Stansby (1982) and Ackman (1989) reported that fishes with lipid content below 5\% are lean fishes.

The major component of fish muscle is moisture. The moisture content of the fishes studied varied between 78.5-80.83\%.The moisture contents for the fish samples were within reasonable range as reported by Gallagher et al (1991). FAO (1999) reported that moisture and lipid contents in fish muscle are inversely related and their sum is approximately $80 \%$ with other components accounting for the remaining 
$20 \%$ which partially agree with the finding of the present study. The findings of this study reveal the nutritional significance of the ecotype cichlid, 'wesafu' above other cichlids of the lagoon.

\section{REFERENCES}

Ackman, R (1989). Nutritional composition of fats in Seafood's. Progressive Nutrition Sciences 13: 161-241.

Alkobaby A.I, Sami .A.S and Ghada I.A (2008). Effect of protein sources on characteristics and quality traits of Nile tilapia (Oreochromis niloticus). $8^{\text {th }}$ International symposium on Tilapia in Aquaculture, Egypt, 12-14 October, 2008 vol.1 551-567pp.

Association of Official Analytical Chemistry (1994). Official Methods of analysis of the Association of Official Chemists. Vol. I and II. Association of Analytical Chemist, Airlington. pp 129.

Fitzsimmons, K. (2008). Review - global advances in tilapia production and marketing. Available at: http://az/arizona.edu.azaqua/ista/Busan 2008ppt.

Food and Agriculture Organization (1999).

World Production of Crustaceans and Molluscs by major fishing areas. Fisheries Information Data and Statistics Unit (FIDI), Fisheries Department, FAO Rome 33pp.
Gallagher M.L, Harrell M.L and Rurilson R.A. (1991). Variation in Lipid and Fatty acid Contents of Atlantic Croakers, Striped Mullet and Summer Flounder. Transactions of the American Fisheries Society, p 614-619.

Hammed A.M, Fashin-Bombatta H.A and Fajana,O.O ( In- Press). Tissue and Blood Acids Composition of an ecotype Cichlid 'wesafu', Tilapia zilli and Oreochromis niloticus using Paper Chromatography. Pakistan Journal of Nutrition.

Henderson R.J and Tocher D.R (2007). The lipid composition and Biochemistry of freshwater fish. Progress lipid Research, 26; 281-347.

Sallam Kh. I, Ahmed A.M, Elgazzar M.M and Eldaly E.A (2007). Chemical quality and sensory attributes of marinated pacific saury (Cololabis saira)during vacuum packaged storage at $4^{0}$ C. Food chemistry, 102;1061-1070.

Stansby M.E (1982) Properties of fish oils and their application to handling of fish and to nutritional and industrial use Pp+5-92. In: Martin, R.E., Flick G.J., Hebard, C.E and Ward D.R. (Eds) Chemistry and Biochemistry of marine food products. Ayi Publishing Co, Westport C.T.

Vlieg (1984). Proximate Composition of New Zealand Slender tuna (Allothunnus fallai). New Zealand Journal of Science 27(4): 427-433.

Table 1: Proximate Composition of Wild specimen of cichlid in Epe Lagoon

\begin{tabular}{lllll}
\hline \multicolumn{5}{c}{ Proximate Composition } \\
\hline Species & Moisture \% & Ash \% & Lipid \% & Crude Protein \% \\
S. galileus & 79.33 & 1.75 & 0.65 & 18.34 \\
S. melatheron & 80.35 & 1.75 & 0.82 & 19.13 \\
$T$. guineesis & 81.70 & 1.00 & 0.40 & 18.71 \\
T. mariae & 80.83 & 1.30 & 0.60 & 18.08 \\
"Wesafu " & 78.50 & 1.20 & 0.90 & 21.80 \\
\hline
\end{tabular}

